\title{
Women's Fertility across the Cycle Increases the Short-Term Attractiveness of Creative Intelligence
}

\author{
Martie G. Haselton \\ University of California, Los Angeles \\ Geoffrey F. Miller \\ University of New Mexico
}

\begin{abstract}
Male provisioning ability may have evolved as a "good dad" indicator through sexual selection, whereas male creativity may have evolved partly as a "good genes" indicator. If so, women near peak fertility (midcycle) should prefer creativity over wealth, especially in short-term mating. Forty-one normally cycling women read vignettes describing creative but poor men vs. uncreative but rich men. Women's estimated fertility predicted their short-term (but not long-term) preference for creativity over wealth, in both their desirability ratings of individual men $(r=.40, p<.01)$ and their forced-choice decisions between men $(r=.46, p<.01)$. These preliminary results are consistent with the view that creativity evolved at least partly as a good genes indicator through mate choice.
\end{abstract}

KEY WORDS: Art; Business; Creativity, Female mate choice; Fertility; Good genes; Intelligence; Menstrual cycle; Mental fitness indicators; Ovulation; Psychological attractiveness; Wealth

Oreat reativity is sexy, but many think that's a by-product of mate choice gone awrydebauched by the superficial charms of novelty and playfulness. Wealth is also sexy, and many think that it is a perfectly sensible form of economic and reproductive decision-making. In this study we challenge these popular views by examining

Received June 30, 2004; revisions requested September 22, 2004; revised version accepted January 11,2005 .

Address all correspondence to Martie G. Haselton. Department of Psychology, 405 Hilgard Avenue, UCLA, Los Angeles, CA 90095-1538.Emall·haselton@ucla.edu 
how women's preferences for creativity vs. wealth change across the ovulatory cycle. This is a single study, and we regard the evidence as preliminary, but the effects are fairly strong, and we hope this work inspires more thought about the role of sexual selection for creative intelligence in human evolution.

\section{FITNESS INDICATOR THEORY}

Some distinctive human traits may have evolved through mutual mate choice as good genes indicators, or "fitness indicators" (Miller 2000a, 2000b). Fitness indicators are conspicuously variable, heritable traits that reveal mutation load fairly accurately because their development is massively polygenic, energetically costly, and/or easily disrupted (Michod and Hasson 1990; Zahavi and Zahavi 1997). Under sexual selection, such traits will tend to grow ever larger, costlier, more complex, and more polygenic, so they function as ever more reliable indicators of genetic quality (Houle and Kondrashov 2002; Møller and Alatalo 1999; Rowe and Houle 1996). The peacock's tail is the classic example of a reliable fitness indicator that predicts offspring survival and reproductive prospects (Møller and Petrie 2002; Petrie 1994). The traditional distinction between runaway sexual selection and good genes sexual selection is breaking down, as more inclusive theories of mate choice emphasize that multiple fitness indicators can evolve in a species that predict both the survival (viability) and reproductive (sexy sons/daughters) prospects of offspring (e.g., Fawcett and Johnstone 2003; Iwasa and Pomiankowski 1999; Kokko et al. 2002, 2003). Mate choice for fitness indicators maximizes offspring viability and attractiveness, and it purges lineages of harmful mutations, thereby lowering the equilibrium mutation load that accounts for much of the heritable variation in fitness under mutation-selection balance (Atmar 1991; Kondrashov 1995; Ridley 2001). Despite sexual selection's mutation-purging power, recent papers suggest that most humans carry a much higher load of deleterious mutations than previously thought, and individuals differ substantially in mutation load - in other words, in the coefficients of additive genetic variance (CVa) in fitness-related traits (e.g., Crow 1999; Kondrashov 2003; Nachman and Crowell 2000; Sunyaev et al. 2001). This substantial mutation load remains not because mutation-purging sexual selection is weak, but because there are so very many genetic loci to be kept mutation-free (Rowe and Houle 1996). Therefore, the incentives for good genes mate choice based on fitness indicators remain much higher than previously expected.

Past research suggests that many human physical traits may function as fitness indicators - as cues of viability, fertility, and/or genetic quality. In males, these fitness-indicator traits appear to include height, upper-body musculature, beard growth, jaw size, brow ridge size, and facial attractiveness; in females, they include breasts, buttocks, waists, skin condition, and facial attractiveness (Barber 1995; Fink et al. 2001; Frederick and Haselton 2004; Grammer et al. 2003; Henderson and Anglin 2003; Hughes and Gallup 2003; Langlois et al. 2000; Manning et al. 1997; Mueller and Mazur 2001; Pawlowski 1999; Scheib et al. 1999; Shackelford and Larsen 1999; 
Singh 1995; Soler et al. 2003; Thornhill and Grammer 1998). Many researchers have also argued that some of our mental traits and behavioral propensities evolved as fitness indicators, according to the principles of costly signaling theory. These mental fitness indicators may include some of our capacities for:

- intelligence (Crow 1996; Furlow et al. 1997; Houle 2000; Miller 2000c; Prokosch et al. 2005; Zechner et al. 2001),

- creativity (Eysenck 1995; Kanazawa 2000; Miller 1997; 1999a; Shaner et al. 2004),

- status-seeking (Barkow 1989; Buss 2003; Perusse 1993),

- language (Burling 1986; Dessalles 1998; Dunbar et al. 1997; Miller 2000a),

- art (Boas 1955; Hirn 1900; Kohn and Mithen 1999; Miller 2001),

- music (Darwin 1871; Miller 2000d; Sluming and Manning 2000),

- conspicuous altruism (Boone 1998; Goldberg 1995; Hawkes 1993; Hawkes et al. 2001; Lotem et al. 2003; Smith and Bird 2000; Sosis et al. 1998; Tessman 1995; Zahavi and Zahavi 1997), and

- conspicuous consumption (Conniff 2002; Miller 1999b; Robson 2001; Saad and Gill 2000; Veblen 1899).

How can we tell whether these traits evolved, at least partly, as fitness indicators through mate choice? This paper suggests a way to identify mental fitness indicators by examining ovulatory cycle shifts in women's mate preferences. There are at least 12 published papers examining cycle effects on women's responses to male traits. Of these, five papers considered male sex pheromones (Gangestad and Thornhill 1998; Grammer 1993; Rikowski and Grammar 1999; Thornhill and Gangestad 1999; Thornhill et al. 2003), six considered male facial features (Johnston et al. 2001; Koehler et al. 2002; Penton-Voak and Perrett 2000, 2001; Penton-Voak et al. 1999), and one considered male behavioral dominance (Gangestad et al. 2004). Of these 12 published studies, 11 found increased preferences for presumptive male fitness indicators at peak fertility; only Koehler et al. (2002) found no effect of female cycle on female mate preference. However, thus far no published studies have considered possible cycle effects on women's preferences for such male mental traits as intelligence, creativity, or sense of humor. Here, we study cycle effects on women's preferences for male creative intelligence as compared with male resources.

What exactly is "creative intelligence"? Although there is no firm consensus on how to define it, we often know it when we see it. We also know a bit about it from a century of creativity research (Sternberg 1999). Across species, creative intelligence seems closely associated with the complexity of foraging, communication, and social life (MacPhail and Bolhuis 2001; Mesulam 1998). Within humans, creative intelligence is closely associated with the highly heritable $g$ factor, or general intelligence (Eysenck 1995; Jensen 1998), and creative intelligence seems to rely on the promiscuous generation, selective elaboration, and skillful implementation of ideas and strategies (Campbell 1960; Simonton 1999). The problem is that creativity sounds desirable, as does intelligence, so "creative intelligence" can become a vague honorific term that seems useful for solving any behavioral problem, whether technological, ecological, social, sexual, or cultural. 
Thus, little progress has been made in testing the many plausible adaptive functions that may explain the origins of human creative intelligence, which include tool-making and tool-using (Ambrose 2001; Von Schaik et al. 1999); hunting, extractive foraging, and food preparation (Hawkes et al. 2001; Kaplan et al. 2000; Robson and Kaplan 2003); social strategizing within and between groups (Barkow 1989; Dunbar 1993; Whiten and Byrne 1997); adaptation to novel econiches through cultural traditions and cultural group selection (Boyd and Richerson 1995; Laland et al. 1999; Tooby and Cosmides 1992); and sexual courtship (Darwin 1871; Miller 2000a). We thought that this cacophony of competing theories might be resolved by stepping back a bit and looking not at the trait itself, but at some evolved adaptations for judging the trait. This led us to look for ovulatory cycle shifts in female preferences for creative intelligence, modestly defined for the purpose of our study as the ability to create novel artistic works or novel and profitable business ideas appreciated by experts in these fields. (See below for further discussion of this working definition.)

\section{GOOD GENES VERSUS GOOD DADS}

Most women face trade-offs in mating. In selecting a long-term mate, it makes sense for women to put greater weight on traits that advertise ability and willingness to invest in protection, provisioning, and care of the woman and her offspring. This will favor the evolution of "good dad" indicators-reliable cues of paternal investment ability and willingness (Hoelzer 1989; Iwasa and Pomiankowski 1999; Kaplan et al. 2000; Kokko 1998). Some women of very high mate value may have the luxury of attracting a long-term mate who has both good dad potential and good genes. Many women have to settle for a committed partner who is not ideal either paternally or genetically. Such women have incentives to secure better genes or better paternal care from short-term or extra-pair partners. Either would help at any time.

However, because the costs and risks of short-term and extra-pair mating extend throughout the cycle, but the good genes benefits can be obtained only during the high fertility phase just before ovulation, women in the high-fertility phase who are seeking short-term mates should value good genes indicators more highly, relative to good dad indicators (Gangestad et al. 2004). This is not to say that ovulating women will show an absolute preference for all good genes indicators over all good dad indicators, only that good genes indicators should become relatively more attractive and more often favored as fertility increases. This may be manifest as a shift from seeing a male trait as marginally distasteful to seeing it as mildly intriguing (as may be the case with male pheromones or aggressive dominance as fitness indicators), or from seeing it as moderately attractive to seeing it as very arousing (as may be the case with male musical or athletic virtuosity).

Conversely, women in the low-fertility phases should show a relatively stronger preference for male traits that advertise immediate resource availability (Buss 1989; 
Geary 2000; Robson and Kaplan 2003). Thus, we expect to see ovulatory cycle shifts in female preferences for fitness indicators vs. resource indicators, especially in short-term mating. This shift should be especially clear if the resource indicators are unconfounded from the fitness indicators, as when resources are acquired through luck or happenstance. A hungry nonfertile female may not mind whether a male hunter's gift of meat was acquired through nonheritable luck (e.g., a windfall of dodo bird meat) rather than heritable skill (e.g., a hard-won slab of giraffe meat that took a week of tracking to acquire). On the other hand, a hungry fertile female should care about luck vs. skill in resource acquisition, and about heritable fitness indicators that have no immediate resource payoffs. Thus, insofar as creative intelligence functions as a mental fitness indicator (or good genes indicator), we expect women at peak fertility, mid-cycle in the late follicular phase, to show stronger preferences for it relative to resource-indicator traits.

In the real world, it is likely that creative intelligence and resource-acquisition ability are valued as both good genes indicators and good dads indicators. They may reveal heritable genetic quality and paternal investment ability to some extent. For example, creativity and wealth in modern societies are both substantially predicted by general intelligence (Eysenck 1995; Jensen 1998). Intelligence can plausibly function as a good genes indicator because it is easily and accurately judged, is highly stable across life and heritable across generations, and shows substantial phenotypic and genetic correlations with creativity, brain size, mental health, physical health, longevity, body symmetry, physical attractiveness, sexual desirability, and success in many domains of life (David et al. 1997; Deary et al. 2000; Eysenck 1995; Furlow et al. 1997; Gottfredson and Deary 2004; Jensen 1998; Li et al. 2002; Lubinski and Humphreys 1997; Postuma et al. 2002; Prokosch et al. 2005; Reynolds and Gifford 2001; Zebrowitz et al. 2002). Equally though, intelligence can function as a good dads indicator because it predicts academic success, economic success, social status, and marital stability (Jensen 1998; Kuncel et al. 2004; Lubinski and Humphreys 1997). Thus, it is difficult to determine whether some mental traits are more desired as indicators of heritable genetic quality or as indicators of future relationship success and parental investment ability.

We tried to resolve this issue by creating mate-choice vignettes that describe potential male mates who have either (1) a lot of creative intelligence and a little money or (2) a little creative intelligence and a lot of money. The vignettes were constructed so the creative intelligence level was potentially, implicitly heritable, but the money level was a windfall reflecting no heritable male traits. As we will discuss later, it is difficult to construct vignettes that unconfound fitness indicators and resource indicators in psychologically and ecologically plausible ways. Also, we have isolated just one facet of the "good dad" construct in this work-current resources-though clearly other good dad qualities play a role in long-term mate choice. For these reasons, this research represents a first step rather than the final word.

Based on previous ovulatory cycle research on morphological indicators of physi- 
cal health, hormone levels, and genetic quality, we expected that women at peak fertility just before ovulation would favor men of the first type, who were creative but poor, especially for short-term sexual relationships. Even in a brief affair, good genes as advertised by creative intelligence could be passed on to offspring, and resources may not matter as much since the male might not be expected to support those offspring. By contrast, women in less fertile phases of the cycle should find good genes indicators less important, and should care more about male wealth.

In long-term mate choice, cycle effects should be nullified or weakened because selection should have shaped women's preferences to act as if they maximize the net benefits of good genes and good dad potential across all future expected cycle phases during which the woman will be with any particular man. If a woman expects to stick with a mate for 10 years (i.e., the next 120 ovulatory cycles, discounting pregnancy and lactation-see Strassman 1997), then her choice should not be affected by whether she is ten days or twenty days into the current ovulatory cycle (Penton-Voak et al. 1999). This reasoning led us to a two simple predictions, which we tested in a questionnaire-based experiment:

Prediction 1: When women rate a man's desirability as a short-term sexual partner, the higher their fertility (as estimated from their cycle phase), the more they should be willing to trade off wealth in favor of creative intelligence. Given a choice between a creative but poor man and an uncreative but rich man, high-fertility women should tend to choose the former more than low-fertility women.

Prediction 2: When women rate a man's desirability as a long-term mate, fertility should have little or no effect on the relative importance of creative intelligence vs. wealth.

\section{METHOD}

\section{Participants}

Forty-one heterosexual female students were recruited from a large university in the western United States. Their average age was 20.1 (s.d. $=3.0$, range $=18-36$ ). In exchange for participating, they received partial credit toward the research requirement of a psychology course. All participants were normally cycling. They reported that were not currently pregnant or breast-feeding, and were not taking any form of hormonal contraception such as the Pill, the Patch, or the Implant. The majority (70.7\%) of the participants were Euro-Americans or Asian-Americans.

\section{Procedure}

Between five and eight participants completed the experiment in each scheduled session. Each participant read and signed a consent form and was assigned to a computer. Cubicle-type barriers separated the computers so participants could not see each other's answers. The questionnaire described below was presented on the 
computer screen, and responses were recorded by mouse-clicks or keypad entries. Participants were debriefed afterwards.

\section{Materials}

Participants read two sets of vignettes about potential male mates. One set described two artists and one set described two businessmen. Art and business were chosen as two contrasting domains of work. Each requires distinct styles of creative intelligence, but both demand combinations of practical and theoretical skills, individual effort and social interaction, and careful product development and flashy marketing. Hence, merit-based success in either domain may function as a mental fitness indicator (Miller 2000a).

In each domain (art or business), one vignette described a man who showed high creative intelligence in his work but who was poor owing to bad luck and adverse circumstances. The other vignette in each set described a man who was average on creative intelligence but was wealthy owing to good luck and beneficial circumstances. Thus there were four men in total for the women to rate as potential mates: a creative but poor artist, an uncreative but rich artist, a creative but poor businessman, and an uncreative but rich businessman. All vignettes made it clear that each man's creativity level was largely endogenous, reflecting natural (and presumably heritable) talent, but that his wealth level was largely accidental, gained through no merit or fault of his own. (See the appendices for the complete vignettes.)

Presentation order for the vignettes was fully counterbalanced. Half of the participants read the artist vignettes first; the others read the businessman vignettes first. Also, within each pair, half of the participants read about the creative-butpoor man first, and the others read about the uncreative-but-rich man first.

Following each pair of vignettes, participants responded to six questions: two forced-choice questions and four desirability ratings. First, they completed the forcedchoice questions: (1) "Based on these descriptions, who do you think you might find more desirable for a short-term sexual affair?" (2) "Based on these descriptions, who do you think you might find more desirable for a long-term committed relationship?" Participants selected the chosen man's first initial, as specified in the vignettes ( $L$ or $M$ in the artist vignettes, and $R$ or $J$ in the entrepreneur vignettes).

Next, participants rated the desirability of each man as a short-term mate and as a long-term mate on two 9-point scales (where $1=$ not at all desirable, $5=$ average, and $9=$ extremely desirable). The rating questions were as follows: "Overall, how desirable would you find $\mathrm{L}[\mathrm{M}, \mathrm{R}$, or $\mathrm{J}]$ as a long-term partner?" "Overall, how desirable would you find $\mathrm{L}[\mathrm{M}, \mathrm{R}$, or $\mathrm{J}]$ as a short-term partner?" The following definitions were provided immediately before these ratings: "LONG-TERM PARTNER= people with whom you would desire a long-term committed romantic relationship;" "SHORT-TERM PARTNER = people with whom you would desire a one-night stand or brief affair."

After reading all four vignettes and completing the six questions per pair of 
vignettes, participants reported the date on which they expected their next menstrual period to begin. Calendars were provided for reference.

\section{Fertility Estimation}

The menstrual cycle information provided was used to predict each participant's fertility level on the day of the experiment. We used the reverse-cycle-day method to calculate each participant's fertility (Lenton, Landgren, and Sexton 1984; Pillsworth, Haselton, and Buss 2004) since it takes into account individual cycle length and provides control for the variation in the first half (follicular phase) of the cycle. Following Thornhill and Gangestad (1999), we estimated the day of ovulation to be 15 days prior to next menstrual onset, determined each participant's number of days before or after expected ovulation, and estimated each participant's actuarial fertility on the day of the experiment, using data on pregnancy rates across the cycle (Jöchle 1973). Actuarial fertility is the probability on any given day of the cycle of becoming pregnant, if copulation occurs on that day.

Using this method, actuarial fertility varies between $0.1 \%$ and $40.8 \%$. There is a steady increase in conception risk prior to ovulation (increasing from $17.7 \%$ to $32.6 \%$ on the five days prior to the average day of ovulation), a peak at ovulation (reverse cycle day $15=40.8 \%$ ), and a steep decline after ovulation (dropping to $4.8 \%$ four days after the average day of ovulation). In our sample, mean actuarial fertility was $9.7 \%$ (s.d. $=12.1 \%$ ). Actuarial fertility was used as a continuous variable in the correlational analyses reported below. We also created a dichotomized variable. There is a precipitous drop off in fertility within the third to fifth day following the average day of ovulation (from $10.5 \%$ to $2.5 \%$ ). We placed all women with fertility estimates at or above $10.5 \%$ in the high fertility group $(n=15$; mean fertility $=21.5 \%)$ and all other women in the low fertility group $(n=26$; mean fertility $=2.1 \%$ ).

\section{RESULTS}

\section{Notes on Significance Tests}

Directional predictions were tested using directed tests, whereas unpredicted effects were tested using standard two-tailed tests. Directed tests split a $0.05 p$-value into 0.04 in the predicted direction and 0.01 in the unpredicted direction (see Rice and Gaines 1994).

\section{Desirability Ratings of Creative Intelligence vs. Wealth}

Table 1 presents the correlations between fertility and the ratings of each man's desirability as a short-term mate and as a long-term mate. Confirming prediction 1, fertility was significantly and positively associated with the short-term desirability 
Table 1. Correlations between Estimated Fertility and Ratings of Artists' and Entrepreneurs' Desirability as Short-Term and Long-Term Mates

\begin{tabular}{lcc}
\hline & Short-Term & Long-Term \\
\hline Creative but poor artist & $.406^{* *}$ & -.022 \\
Creative but poor businessman & $.287^{*}$ & .182 \\
Uncreative but rich artist & -.147 & .215 \\
Uncreative but rich businessman & -.048 & .044 \\
\hline
\end{tabular}

${ }^{*} p<.05, * * p<.01 ; N=41$

of the creative-but-poor men (see first two entries in the left column). Fertility had no significant effect on the short-term desirability of the uncreative-but-rich men (last two entries in the left column). Confirming prediction 2, this fertility effect was limited to the short-term mating context. There was no significant fertility effect on the long-term desirability of any man (all four entries in the right column in Table 1 are not significant.) To verify this pattern we conducted a General Linear Models (GLM) analysis (SPSS 12.0) in which we tested the predicted three-way interaction between fertility status, creative vs. rich target, and short- vs. long-term desirability. The analysis had three within-subjects factors (creative vs. rich, shortvs. long-term, and art vs. business) and one quantitative between-subjects factor (fertility). The predicted three-way interaction was significant $\left(\mathrm{F}_{1,39}=4.67, p=\right.$ $0.04)$. This interaction was not qualified by a higher-order interaction with the art vs. business factor $(p=0.20)$.

We formed a composite rating of the short-term desirability of creative intelligence across both work domains (art and business). This composite was reliable ( $\alpha$ $=0.70$ ), and positively correlated with fertility $\left(r_{41}=0.40, p<0.01\right.$; Figure 1$)$. The other three possible composites across the artists and businessmen (i.e., short-term desirability of wealth; long-term desirability of creative intelligence or wealth) showed low reliabilities ( $\alpha=0.36$ or lower), and none showed significant correlations with fertility $(p>0.24$ in each case).

\section{Forced-Choice Responses}

Participants also made the two forced-choice decisions between the men in each work domain (art or business) by choosing which man they would prefer as a shortterm partner, and which man they would prefer as a long-term partner. These forcedchoice responses may reveal more clearly how women deal with trade-offs between the good genes indicator (creative intelligence) and the good dad indicator (wealth). Below we report tests of our predictions when aggregating across the two work domains using a continuous fertility measure, and separately within each domain using a dichotomized fertility measure.

We aggregated the forced-choice items across work domains to form a creativity preference index for both the short-term and long-term mating contexts. We com- 
Figure 1. Correlation of fertility and short-term ratings of creatively intelligent men.

\section{Correlation of Fertility and Short-Term Ratings of Creatively Intelligent Men $(r=.40, p=.01)$}

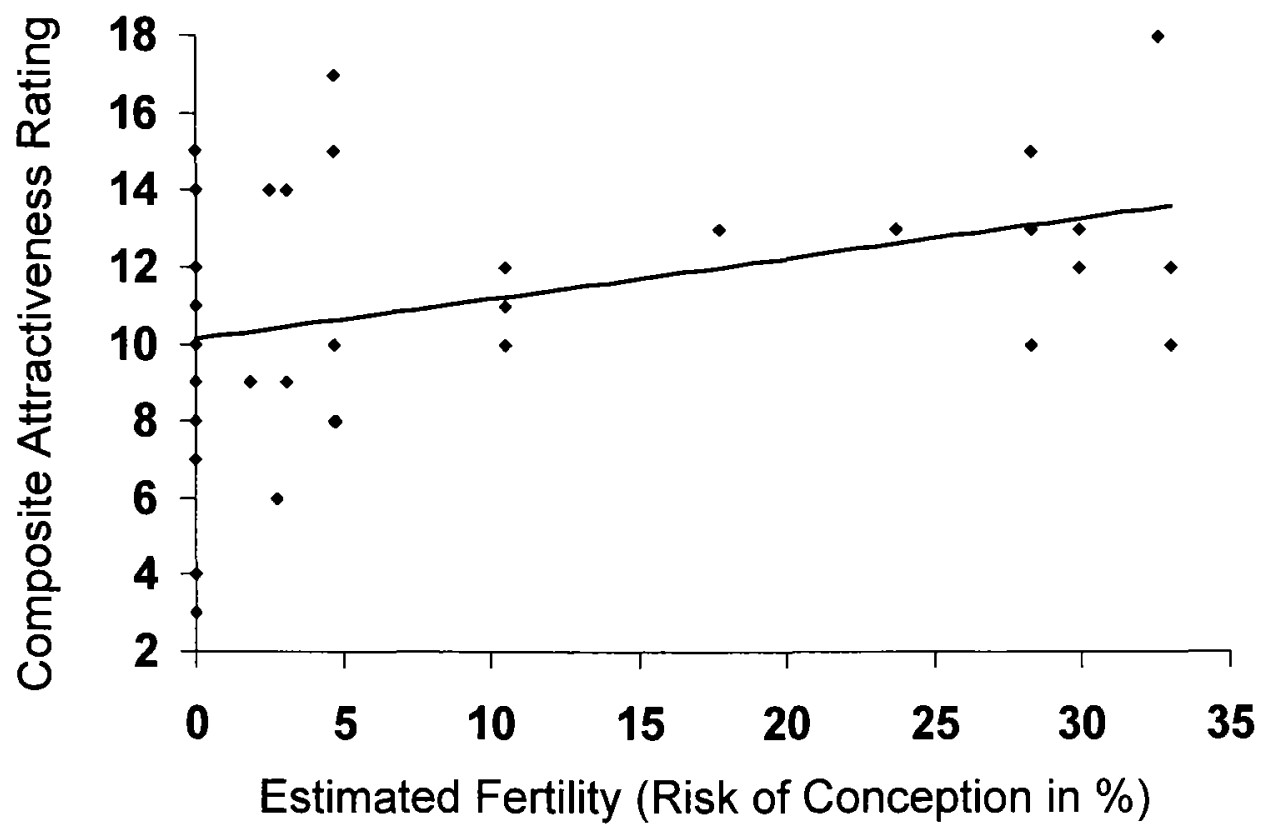

puted this index by adding up the number of times each participant favored creativity over wealth across both the art and business domains. For example, the shortterm creativity preference index equaled 0 if a participant always favored wealth in short-term mating, 1 if a participant favored wealth once and creativity once, and 2 if a participant always favored creativity. The long-term creativity preference variable was computed in the same way.

Prediction 1 was again confirmed: for short-term mating, fertility was positively correlated with the creativity preference index $\left(r_{41}=0.46, p<0.01\right)$. Prediction 2 was also confirmed again: for long-term mating, fertility had no significant correlation with the creativity preference index $\left(r_{41}=-0.02, p=0.89\right)$. We verified this pattern by testing the predicted interaction between short vs. long-term desirability and fertility status in a GLM analysis with short vs. long-term desirability as a within-subjects factor and fertility status as a quantitative between-subjects factor. The predicted interaction was significant $\left(\mathrm{F}_{1,39}=6.61, p=0.01\right)$.

We cross-tabulated each forced-choice response with the dichotomized fertility variable. For a short-term relationship, the creative-but-poor businessman was chosen more often by high-fertility women than by low-fertility women (Fisher's exact probability, one-sided $=0.016$; Figure 2 ). For a short-term relationship, the creative-but-poor artist was also chosen more often by high-fertility women than by 
Figure 2. Preference for creativity as a function of dichotomized fertility: Short-term choice.

\section{Preference for Creativity as a Function of Dichotomized Fertility: Short-Term Choice}

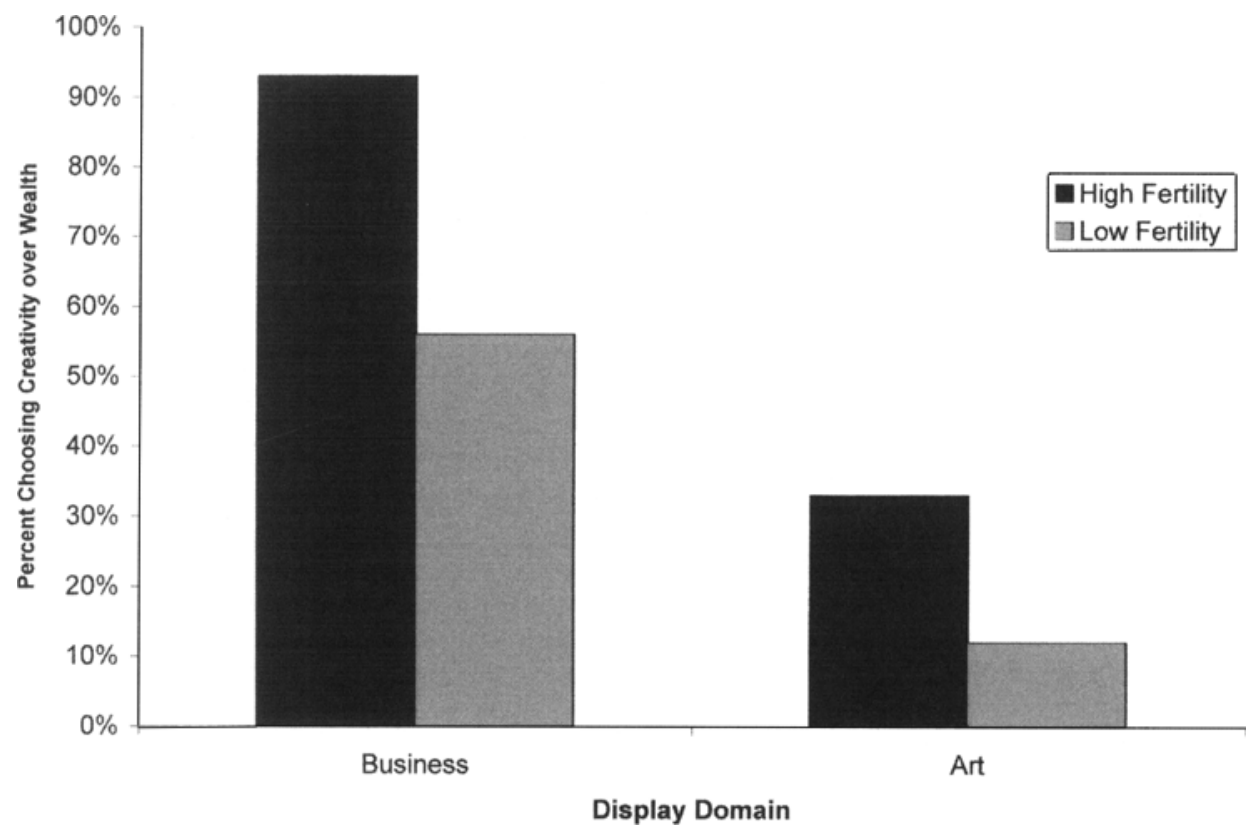

low-fertility women (see Figure 2). This difference, however, was not statistically significant (Fisher's exact probability, one-sided $=0.101$ ). As noted in the introduction, we expect fertility to increase the preference for fitness indicators relative to resource indicators, not necessarily to boost the fitness indicator preference above a $50 \%$ popularity threshold in these forced-choice decisions.

In contrast, and in accordance with prediction 2 , dichotomized fertility had no effect on long-term forced-choice preferences. For a long-term relationship, the creative-but-poor businessman was chosen about equally often (Fisher's exact probability $=1.00)$ by the high-fertility women $(66.7 \%)$ and the low-fertility women $(65.4 \%)$. Likewise, for a long-term relationship, the creative-but-poor artist was chosen about equally often (Fisher's exact probability $=1.00$ ) by the high-fertility women $(86.7 \%)$ and the low-fertility women $(84.6 \%)$. Like the continuous measure of quantitative fertility, dichotomized fertility is positively associated with the preference for creative intelligence only in short-term mating, not in long-term mating.

\section{Overall Preferences for Creative Intelligence over Wealth}

Although it was not directly pertinent to our predictions, we examined the overall desirability of creative intelligence vs. wealth across all fertility levels, and a fairly consistent preference for the former emerged (Table 2). In three out of four 
Table 2. Ratings of Artists' and Entrepreneurs' Desirability as Short-term (ST) and Long-term (LT) Mates, Averaging across Fertility

\begin{tabular}{lcccccccc}
\hline & \multicolumn{2}{c}{$\begin{array}{c}\text { Creative- } \\
\text { But-Poor }\end{array}$} & & \multicolumn{2}{c}{$\begin{array}{c}\text { Uncreative- } \\
\text { But-Rich }\end{array}$} & & \\
\cline { 2 - 3 } & Mean & s.d. & & Mean & s.d. & & $t$ & $p<$ \\
\hline Artist's ST attractiveness & 5.29 & 2.02 & & 6.05 & 1.71 & -1.60 & .12 \\
Artist's LT attractiveness & 6.36 & 1.60 & & 4.73 & 1.78 & 3.70 & .01 \\
Businessman's ST attractiveness & 5.85 & 1.61 & & 4.37 & 1.82 & 3.29 & .01 \\
Businessman's LT attractiveness & 6.15 & 1.97 & & 4.59 & 2.01 & & 3.06 & .01 \\
\hline
\end{tabular}

$N=41$

cases $(p<0.01)$, the creative but poor man was rated as more desirable than the uncreative but rich man. The only exception was a nonsignificant short-term preference for the uncreative but rich artist.

Based on the logic of good genes vs. good dads indicators, one might expect a preference for money over creative intelligence for long-term mating. Why was this not found? One possibility is that our vignettes did not fully separate good genes and good dad indicators. Arguably, the creative men displayed future resourceacquisition potential. Although currently poorer than their counterparts, both were college-educated and possessed talents that could eventually translate into wealth. Women evaluating them as long-term mates may have recognized the potential to have the best of both worlds - an interesting, talented, creative mate who might eventually become financially successful. For short-term mating, however, the eventual resource benefits of the creative mate could not be obtained, and hence we observed a shift toward preferring current resources at low fertility (when immediate resource benefits should be valued more than good genes).

\section{DISCUSSION}

Predictions 1 and 2 were supported consistently by both the desirability ratings and the forced-choice decisions in both the art and business domains, whether fertility was represented continuously or dichotomized. As suggested by fitness indicator theory (Miller 2000a, 2000b), fertility increases the desirability of creative intelligence over wealth for short-term mating.

These initial results suggest that male creative intelligence functions, at least in part, as a good genes indicator, and that it may have evolved, at least in part, through female choice for short-term sexual partners. That is, creative intelligence may have evolved in part because it attracted women for brief romances and extra-pair copulations. We suspect that female creative intelligence also evolved as a mental fitness indicator through male mate choice. However, we do not see an analogous way to test that hypothesis since men do not show analogous fertility cycles or cyclic shifts in their preferences. Our results by no means show that sexual courtship was 
the primary or exclusive function driving the evolution of human creative intelligence. They simply suggest that creative intelligence, whatever its original adaptive function(s), came to be valued at some point during human evolution as a good genes indicator.

These results also suggest that male resource-seeking functions, at least in part, as a good dad indicator, and that it may have evolved, at least in part, through female choice for both short-term and long-term provisioners. This is concordant with the views of many researchers that paternal investment, especially through protection and provisioning of mates and offspring, has been crucial in the evolutionary success of hominids (Buss 1989, 2003; Hill and Hurtado 1996; Kaplan et al. 2000). Dads who reliably provided meat for their offspring helped them to bear the energetic costs of encephalization, helped reduce the mortality rate between weaning and sexual maturity, and thereby helped to increase the length and rate of somatic and cortical investment during development (Kaplan et al. 2000; Robson and Kaplan 2003). When women are at low-fertility stages of the cycle, the shifting of their preference toward males who offer resources makes good adaptive sense since these benefits may be immediately obtainable whereas genetic benefits are not. As with female creative intelligence, we suspect that female resource-acquisition ability also evolved in part through male mate choice for long-term sexual partners. Moms who forage more effectively and reliably offer better returns on male investments of mating and parental effort.

These results support an emerging consensus that human female sexuality is adaptively sensitive to trade-offs between good genes and good dads (e.g., Gangestad and Simpson 2000; Scheib 2001; Schmitt and Shackelford 2003; Waynforth 2001). Prior researchers have theorized that ovulatory increases in women's preference for symmetry, facial masculinity, and behavioral dominance, for example, reflect shifting mating priorities in which women place greater emphasis on good genes than on provisioning when they are most fertile (Gangestad and Simpson 2000; Gangestad et al. 2004; Penton-Voak et al. 1999). An important feature of our research is that it is the first to explicitly examine and document trade-offs across the cycle. The results demonstrate that menstrual cycle shifts do not occur for all traits women value in mates-fertility only increased their preference for the purported good genes indicator (creative intelligence).

Our results cannot be explained as a side-effect of increased female sexual desire around ovulation (e.g., Pillsworth et al. 2004; Udry and Morris 1968). A generic libido boost would presumably have made all of the men in the study very attractive (both the men displaying creative intelligence and those displaying wealth) in both work domains (art and business), for both short-term and long-term mating--which is not what we found. Conversely, as we note above, our results also cannot be explained as a side-effect of generally increased choosiness around ovulation. Our results show cycle shifts that are trait-specific.

Our results also cannot be explained by any social-constructivist model of mate choice that we can imagine. It seems unlikely that popular culture, parenting, or 
peer pressure could lead women unconsciously to favor creativity on high-fertility days but not on low-fertility days of their cycles - and only for short-term mating. Even if capitalist patriarchy could condition mate preferences in women, it would presumably favor long-term fidelity to wealthy men all of the time, suppressing any short-term mating desires for creative but poor men.

It is unlikely that the women in the study could have guessed the specific pattern of results we predicted and biased their responses accordingly. Women rated the vignettes before they saw the menstrual cycle questions, and the theory of cycle effects and mating trade-offs was not covered in their psychology course.

This study was small and simple. It had some limitations that could be overcome in further research. Although our predictions were supported with statistically significant results, more statistical power could be obtained through a within-subjects design that tested mate preferences several times for each woman. More powerful designs could be used to examine variation in cycle effects between women, especially as a function of sociosexuality, subjective mate value, partner mate value, and current relationship satisfaction (Gangestad and Simpson 2000; Haselton and Gangestad in press; Mikach and Bailey 1999). The accuracy of fertility estimates could be increased if supplemented by direct measurement of hormone levels (e.g., luteinizing hormone) around ovulation (though inaccuracies in our method of calculating fertility should have worked against finding the significant results we observed). Results could be generalized more confidently if replicated in more diverse female populations, and with more diverse stimuli (e.g., different male mental traits manifest in different work domains and status games).

There are also limitations of the vignette methodology. In creating the vignettes we needed to provide sufficient background details to make them realistic. With increased realism, however, is the drawback of added details unrelated to the intended manipulation. For example, we needed to create a scenario in which an untalented art student could acquire windfall wealth as a result of his artwork, and we therefore explained that his art was created accidentally (through spilled paint). This description may have made him appear to be a goof-off who was lower in conscientiousness than the creative but poor artist. It is possible that this detail is partially responsible for the greater overall preference for the creative-but-poor artist as a long-term mate. In spite of these drawbacks, we found consistent ovulatory shifts in preferences across the two sets of vignettes, suggesting that vignette-specific, personality-attribution effects were not driving the ovulatory cycle effects we observed.

The vignettes could also be improved to distinguish more clearly between the creativity-rich but resource-poor and the creativity-poor but resource-rich. For example, our creative-but-poor artists and businessmen may have been described in a way that led participants to expect their future earning potential to be substantial, despite current poverty. It would also be useful to examine creativity vs. resources trade-offs in many other domains of work and status beyond just painting and business management. The famous sexiness of musicians suggests a particularly promising domain for further research. 
Our artist vignettes could be construed as implying that representational artists are generally more talented than abstract artists. We did not mean to imply a mean difference in artistic skill, only a difference in the difficulty of discerning skill. From the lay person's viewpoint, good representational art is hard to fake, but good abstract art is hard to recognize. We found it plausible to design a vignette in which a relatively untalented artist stumbles upon a new form of abstract art that happens to become popular among wealthy art patrons. We could not envision the converse happening - an untalented artist happening to paint a skilled representational work that commands high prices from patrons and praise from critics.

Future tests of fitness-indicator theory could be conducted using more naturalistic mate-preference measures. For example, future studies may examine ovulatory cycle shifts in women's preference for various male mental traits through video analyses of conversation patterns (Dunbar et al. 1997) or nonverbal flirtation patterns in response to different males (Grammer et al. 1998 2000); responses to singles' ads (e.g., Pawlowski and Dunbar 1999; Pawlowski and Kozeil 2002) or sperm donor profiles (Scheib 1994) containing different descriptors; content analyses of dreams and sexual fantasies (Ellis and Symons 1990; Leitenberg and Henning 1995); person perception biases in mate choice based on implicit cost-benefit models (Haselton and Buss 2000); emotional reactions before, during, and after sex (Haselton and Buss 2001; Thornhill et al. 1995); consumer preferences for different kinds of erotica featuring different kinds of males (Salmon and Symons 2001; Whissell 1996); imagined or actual responses to sexual coercion by males with different traits (Thornhill and Thornhill 1990); judged effectiveness of trait-specific self-promotion and competitor-derogation tactics by males (Schmitt and Buss 1996); studies of geographic, ecological, and economic variation in the relative payoffs of paternal investment, physical health, and male mental abilities (Gangestad and Buss 1993; McGraw 2002); and even the analysis of delusional content regarding different men in women with erotomania, schizophrenia, or borderline personality disorder (e.g., Brüne 2001).

\section{CONCLUSION}

The more closely we examine women's mate preferences, the more intricate are the adaptive design details that we find. Far from reducing human sexuality to a list of simple mating instincts, evolutionary research is revealing the profoundly flexible nature of person perception in the mating domain-flexibility that is responsive not only to the external costs and benefits of short-term vs. long-term relationships, but also to the internal physiological milieu of women's bodies, and the fertility cycles that regulate their reproductive lives.

Women may have evolved to favor the best of both worlds - good genes and good dads-at different points in their ovulatory cycles. Perhaps this makes women seem fickle to their male partners, who are not themselves the best of both. What is most adaptive for women may often be most frustrating_-or mostly invisible - to 
men. Women's bodies and brains follow an adaptive rhythm largely hidden from men, a rhythm that tunes them cyclically to the perils of starvation and mutation, and the intuitive economics of energy flows through ecosystems and the intuitive genetics of information flows through generations. In mate choice, as in everything important, women know that a foolish consistency is the hobgoblin of little minds.

Martie Haselton thanks Robert Liu and Tammy Chow for help in collecting the data, and Michael Mitchell for suggestions for statsstical analysis. Geoffrey Miller thanks Helena Cronin, Laura Dane, Steve Gangestad, Randy Thornhill, and Ron Yeo for useful comments on this line of work. Both authors thank John Tooby for initially suggesting the test of trade-offs between inherited wealth and intelligence, and Rosalind Arden, David Buss, Belinda Campos, Dave Frederick, Steve Gangestad, Elizabeth Pillsworth, Josh Poore, Andrew Shaner, Julie Smurda, and three anonymous reviewers for helpful comments on an earlier draft of this paper.

Martie Haselton is an assistant professor of communication studies at UCLA, with a Ph.D. from the University of Texas at Austin in 2000. Her research concerns female sexuality, ovulatory cycle shifts in women's mate preferences, adaptive biases in social judgment, strategic conflict between the sexes, and adaptationist theory.

Geoffrey Miller is an assistant professor of evolutionary psychology at University of New Mexico, and author of The Mating Mind After earning a Ph.D. from Stanford in 1993, he worked in Britain and Germany until 2001. His research concerns fitness indicator theory, intelligence, behavior genetics, psychopathology, consumer behavior, aesthetics, and morality.

\section{APPENDIX A: ARTIST VIGNETTES}

$\mathrm{M}$ is an art student. $\mathrm{M}$ has always had a passion for painting and plans to pursue a career in art. He creates paintings of people and complex landscapes. His paintings are so lifelike that they are often mistaken for photographs. The consensus among his art professors is that he is, by far, the most talented student they have seen. One professor, an expert on lifelike paintings, says he believes $M$ is one of the most talented artists ever to produce these paintings. To make extra money to support his schooling, $\mathrm{M}$ has sold a few of his best paintings. They have sold for between $\$ 100$ and $\$ 200$. One professor lamented that M's paintings are worth far more, but like so many other artists, he will probably never make very much money selling them.

$\mathrm{L}$ is an art student. He paints abstract paintings. $\mathrm{L}$ came into art by chance. $\mathrm{He}$ took an art class as an elective because it fit well in his schedule. For his midterm project, he produced an abstract painting after an hour of "fooling around" with the paint and canvas. The majority of the painting actually consisted of paint he accidentally spilled onto the canvas. A very wealthy man who was looking for art for his home discovered L's painting in the student art studio. He paid L $\$ 5,000$ for the painting. Some of the man's other wealthy friends liked L's painting and commissioned a total of $\$ 100,000$ in paintings from him. $L$ and his art professors were shocked at the success of L's paintings, because, in the words of one professor, "he has no real talent, just some good luck." L continues to capitalize on his success by selling his abstract art. 
$\mathrm{L}$ and $\mathrm{M}$ are considered highly desirable by other women on campus. Friends of $\mathrm{L}$ and $\mathrm{M}$ say that they are dependable, kind, and generous friends.

\section{APPENDIX B: BUSINESSMAN VIGNETTES}

$J$ is an entrepreneur who had great success in his first business venture. He started a small software business in a friend's garage. His product was a new kind of software for improving factory designs to radically increase the profitability of manufacturing. Within his first year, $\mathbf{J}$ secured contracts with Ford, General Electric, and Boeing. In the next three years, $\mathbf{J}$ sold his software to most of the top manufacturing companies in the United States and several of the top companies in Asia. After 5 years in business, J's company was valued at $\$ 120$ million and had 250 employees. The Wall Street Journal credited the success of J's company to the "brilliance and novelty" of J's product and to J's "sheer genius as a businessman." However, J's company fell victim to misfortune the next year. After $J$ rejected a takeover bid from Microsoft, Microsoft filed a lawsuit claiming that J's software infringed on some of their patents. Although most experts agreed that the suit had no merit, the cost of defending himself against the lawsuit created huge cash flow problems for $J$, which drove the company into bankruptcy. Although $\mathrm{J}$ has very little money left, he has recently begun a new business venture to sell another of the software products he has invented.

$\mathrm{R}$ recently inherited $\$ 20$ million from the couple who had adopted him when he was a year old. They died in a car crash, having made their fortune in commercial real estate. Before they died, $\mathrm{R}$ worked as a sales person at a computer company. Although $\mathrm{R}$ worked at the company for several years, he had not advanced past his starting salary or rank within the company. He went to a community college, but after graduation he didn't feel sure what to do with his life. A friend who was working at the computer company suggested that $\mathrm{R}$ join him and work there. In R's words, "I guess I'm just not very good at this job. At least now I won't have to worry about money any more." $\mathrm{R}$ and his adoptive parents were very close, and he was deeply saddened by their deaths.

$\mathrm{J}$ and $\mathrm{R}$ are both in their mid-twenties. They were recently nominated as two of the most eligible bachelors in Los Angeles.

\section{REFERENCES}

Ambrose, S. H.

2001 Paleolithic Technology and Human Evolution. Science 291:1748-1753.

Atmar, W.

1991 On the Role of Males. Animal Behavior 41:195-205.

Barber, $\mathrm{N}$.

1995 The Evolutionary Psychology of Physical Attractiveness: Sexual Selection and Human Morphology. Ethology and Sociobiology 16:395-424.

Barkow, J.

1989 Darwin, Sex, and Status. Toronto: University of Toronto Press. 
Boas, F. 1955 Primitive Art. New York: Dover.

Boone, J. L.

1998 The Evolution of Magnaminity: When Is It Better to Give Than to Receive? Human Nature 9:1-21.

Boyd, R., and P. J. Richerson

1995 Why Does Culture Increase Human Adaptability? Ethology and Sociobiology 16:125-143.

Brüne, $M$.

2001 De Clérambault's Syndrome (Erotomanıa) in an Evolutionary Perspective. Evolution and Human Behavior 22:409-415.

Burling, R.

1986 The Selective Advantage of Complex Language. Ethology and Sociobıology 7:1-16.

Buss, D. M.

1989 Sex Differences in Human Mate Selection: Evolutionary Hypotheses Tested in 37 Cultures. Behavioral and Brain Sciences 12:1-49.

2003 The Evolution of Desire, second ed. New York: Basic Books.

Campbell, D. T.

1960 Blind Variation and Selective Retention in Creative Thought as in Other Knowledge Processes. Psychological Review 76:380-400.

Conniff, R.

2002 The Natural History of the Rich. A Field Guide. New York: W. W. Norton.

Crow, J. F.

1999 The Odds of Losing at Genetic Roulette. Nature 397:293-294.

Crow, T. J.

1996 Sexual Selection as the Mechanism of Evolution of Machiavellian Intelligence: A Darwinian Theory of the Ongins of Psychosis. Journal of Psychopharmacology 10:77-87.

Darwin, C.

1871 The Descent of Man, and Selection in Relation to Sex, 2 vols. London: John Murray. (Reprinted in 1981 by Princeton University Press)

David, A. S., A. Malmberg, L. Brandt, P. Allebeck, and G. Lewis

1997 IQ and Risk for Schizophrenia: A Population-Based Cohort Study. Psychological Medicine 27:1311-1323.

Deary, I. J., L. J. Whalley, H. Lemmon, J. R. Crawford, and J. M. Starr

2000 The Stability of Individual Differences in Mental Ability from Childhood to Old Age Follow-Up of the 1932 Scottish Mental Survey. Intelligence 28:49-55.

Dessalles, J. L.

1998 Altruism, Status and the Origin of Relevance. In Approaches to the Evolution of Language, J. R. Hurford, M. Studdert-Kennedy, and C. Knight, eds. Pp. 130-147. Cambridge Cambridge University Press.

de Waal, F.

1982 Chimpanzee Politics. New York: Harper and Row.

Dunbar, R. I. M.

1993 Coevolution of Neocortical Size, Group Size, and Language in Humans. Behavioral and Brain Sciences 16:681-735.

Dunbar, R. I. M., A. Marriot, and N. D. C Duncan

1997 Human Conversational Behavior. Human Nature 8:231-246.

Ellis, B., and D. Symons

1990 Sex Differences in Sexual Fantasy: An Evolutionary Approach. Journal of Sex Research $27: 527-556$.

Eysenck, H. J.

1995 Genius: The Natural History of Creativity. Cambridge: Cambridge Unıversity Press.

Fawcett, T. W., and R. A. Johnstone

2003 Optımal Assessment of Multiple Cues Proceedings of the Royal Society of London B 270:1637-1643. 
Fink, B., K. Grammer, and R. Thornhill

2001 Human (Homo sapiens) Attractiveness in Relation to Skın Texture and Color. Journal of Comparative Psychology 115:92-99.

Frederick, D. A., and M. G. Haselton

2004 Is Male Muscularity an Indicator of Good Genes? Evidence from Female Preferences and Male and Female Sexual Experiences. Ms. in the authors' possession, University of California, Los Angeles.

Furlow, B. F., T. Armijo-Prewitt, S. W. Gangestad, and R. Thornhill

1997 Fluctuating Asymmetry and Psychometric Intelligence. Proceedings of the Royal Soctety of London B 264:823-829.

Gangestad, S. W., and D. M. Buss

1993 Pathogen Prevalence and Human Mate Preferences. Ethology and Socioblology 14:89-96.

Gangestad, S. W., and J. A. Simpson

2000 The Evolution of Human Mating: Trade-Offs and Strategic Pluralism. Behavioral and Brain Sciences 23:675-687.

Gangestad, S. W., and R. Thornhill

1998 Menstrual Cycle Variation in Women's Preferences for the Scent of Symmetrical Men. Proceedings of the Royal Society of London B 265:927-933.

Gangestad, S. W., J. A. Simpson, A. J. Cousins, C. E. Garver-Apgar, and P. N Christensen 2004 Women's Preferences for Male Behavioral Displays Change across the Menstrual Cycle. Psychological Science 15:203-207.

Geary, D. C.

2000 Evolution and Proximate Expression of Human Paternal Investment. Psychological Bulletin 126:55-77.

Goldberg, T. L.

1995 Altruism towards Panhandlers: Who Gives? Human Nature 6:79-89.

Gottfredson, L. S., and I. J. Deary

2004 Intelligence Predicts Health and Longevity, But Why? Current Directions in Psychological Science 13:1-14.

Grammer, K.

1993 5-a-androst-16en-3-a-on: A Male Pheromone? A Brief Report. Ethology and Sociobiology 14: 201-207.

Grammer, K., K. B. Kruck, and M. S. Magnusson

1998 The Courtship Dance: Patterns of Nonverbal Synchronization in Opposite-Sex Encounters. Journal of Nonverbal Behavior 22:3-29.

Grammer, K., J. Kruck, A. Juette, and B. Fink

2000 Non-Verbal Behavior as Courtship Signals: The Role of Control and Choice in Selecting Partners. Evolution and Human Behavior 21:371-390.

Grammer, K., B. Fink, A. P. Møller, and R. Thornhill

2003 Darwinian Aesthetics: Sexual Selection and the Biology of Beauty. Biological Reviews 78:385-407.

Haselton, M. G., and D. M. Buss

2000 Error Management Theory: A New Perspective on Biases in Cross-Sex Mindreading. Journal of Personality and Social Psychology 78:81-91.

2001 The Affective Shift Hypothesis: The Functions of Emotional Changes Following Sexual Intercourse. Personal Relationships 8:357-369.

Haselton, M. G, and S. W. Gangestad

in press Conditional Expression of Women's Desires and Men's Mate Guarding across the Ovulatory Cycle. Hormones and Behavior

Hawkes, $\mathrm{K}$.

1993 Why Hunter-Gatherers Work: An Ancient Version of the Problem of Public Goods. Current Anthropology 34:341-361.

Hawkes, K., J. F. O'Connell, and N. G. Blurton Jones

2001 Huntıng and Nuclear Families: Some Lessons from the Hadza about Men's Work. Current Anthropology 42:681-709. 
Henderson, J. J. A., and J. M. Anglın

2003 Facial Attractiveness Predicts Longevity. Evolution and Human Behavior 24:351-356.

Hill, K., and A. M. Hurtado

1996 Ache Life History. New York: Aldine de Gruyter.

Hirn, Y.

1900 The Origins of Art. A Psychological and Sociological Inquiry. New York: Macmillan.

Hoelzer, G. A.

1989 The Good Parent Process of Sexual Selection. Animal Behavior 38:1067-1078.

Houle, D.

2000 Is There a $g$ Factor for Fitness? In The Nature of Intelligence, G. Bock, J. Goode, and $\mathrm{K}$. Webb, eds. Pp. 149-170. Novartis Foundation Symposium 233. New York: John Wiley.

Houle, D., and A. S. Kondrashov

2002 Coevolution of Costly Mate Choice and Condition-Dependent Display of Good Genes. Proceedings of the Royal Society of London B 269:97-104.

Hughes, S. M., and G. G. Gallup, Jr.

2003 Sex Differences in Morphological Predictors of Sexual Behavior: Shoulder to Hip and Waist to Hip Ratios. Evolution and Human Behavior 24:173-178.

Iwasa, Y., and A. Pomiankowski

1999 Good Parent and Good Genes Models of Handicap Evolution. Journal of Theoretcal Biology 200:97-109.

Jensen, A. R.

1998 The $\mathrm{g}$ Factor: The Science of Mental Ability. Westerport, Connecticut: Praeger.

Jöchle, W.

1973 Coitus-Induced Ovulation. Contraception 7:523-564.

Johnston, V. S., R. Hagel, M. Franklin, B. Fink, and K. Grammer

2001 Male Facial Attractiveness: Evidence for Hormone-Mediated Adaptive Design. Evolution and Human Behavior 22:251-267.

Kanazawa, S.

2000 Scientific Discoveries as Cultural Displays: A Further Test of Miller's Courtship Model. Evolution and Human Behavior 21:317-321.

Kaplan, H. S., K. Hill, J. Lancaster, and A. M. Hurtado

2000 A Theory of Human Life History Evolution: Diet, Intelligence, and Longevity. Evolutionary Anthropology 9:156-185.

Koehler, N., G. Rhodes, and L. W. Simmons

2002 Are Human Female Preferences for Symmetrical Male Faces Enhanced When Conception Is Likely? Animal Behavior 64:233-238.

Kohn, M., and S. Mithen 1999 Handaxes: Products of Sexual Selection? Antiquity 73:518-526.

Kokko, $\mathrm{H}$.

1998 Should Advertising Parental Care Be Honest? Proceedings of the Royal Soclety of London B 265:1871-1878.

Kokko, H., R. Brooks, J. M. McNamara, and A. I. Houston

2002 The Sexual Selection Contınuum. Proceedings of the Royal Society of London B 269:13311340.

Kokko, H., R. Brooks, M. D. Jennions, and J. Morley

2003 The Evolution of Mate Choice and Mating Brases. Proceedings of the Royal Society of London B 270:653-664.

Kondrashov, A.

1995 Contamınation of the Genomes by Very Slightly Deleterious Mutations: Why Have We Not Died 100 Times Over? Journal of Theoretical Biology 175:583-594.

2003 Direct Estimates of Human Per Nucleotıde Mutation Rates at 20 Loci Causing Mendelian Diseases. Human Mutation 21:12-27.

Kuncel, N. R., S. A. Hezlett, and D. S. Jones

2004 Academic Performance, Career Potential, Creatıvity, and Job Performance: Can One Construct Predict Them All? Journal of Personality and Social Psychology 86:148-161. 
Laland, K. N., J. Odling-Smee, and M. W. Feldman

1999 Niche Construction, Biological Evolution, and Cultural Change. Behavioral and Brain Sciences 23:131-175.

Langlois, J. H., L. Kalakanıs, A. J. Rubinstein, A. Larson, M. Hallam, and M. Smooth

2000 Maxims or Myths of Beauty? A Meta-analytical and Theoretical Review. Psychologıcal Bulletin 126:390-423.

Leitenberg, H., and K. Henning

1995 Sexual Fantasy. Psychological Bulletin 117:469-496.

Lenton, E. A., B. M. Landgren, and L. Sexton

1984 Normal Variation in the Length of the Luteal Phase of the Menstrual Cycle: Identification of the Short Luteal Phase. British Journal of Obstetrics and Gynaecology 91:685-689.

Lı, N. P., D. T. Kenrick, J. M. Bailey, and J. A. W. Linsenmeier

2002 The Necessities and Luxuries of Mate Preferences: Testıng the Tradeoffs. Journal of Personality and Social Psychology 82:947-955.

Lotem, A., M. A. Fishman, and L. Stone

2003 From Reciprocity to Unconditional Altruism through Signaling Benefits. Proceedings of the Royal Society of London B 270:199-205.

Lubınski, D., and L. G. Humphreys

1997 Incorporatıng General Intellıgence into Epidemiology and the Social Sciences. Intelligence 24:159-201.

MacPhail, E. M., and J. J. Bolhuis

2001 The Evolution of Intelligence: Adaptive Specialızations vs. General Process. Biological Reviews 76:341-364.

Manning, J. T., D. Scutt, G. H. Whitehouse, and S J. Leinster

1997 Breast Asymmetry and Phenotypic Quality in Women. Evolution and Human Behavior $18.223-236$.

McGraw, K. J.

2002 Environmental Predictors of Geographic Varıation in Human Mating Preferences. Ethology 108:303-317.

Mesulam, M. M

1998 From Sensation to Cognition. Brain 121:1013-1052.

Michod, R. E., and O. Hassan

1990 On the Evolution of Reliable Indicators of Fitness. American Naturalist 135.788-808.

Mikach, S. M., and J. M. Bailey

1999 What Distinguishes Women with Unusually High Numbers of Sex Partners? Evolution and Human Behavior 20:141-150.

Miller, G. F.

1997 Protean Primates: The Evolution of Adaptive Unpredictability in Competition and Courtship. In Machiavellian Intelligence II: Extensions and Evaluations, A. Whiten and R. W. Byrne, eds. Pp. 312-340. Cambridge: Cambridge Unıversity Press.

1999a Sexual Selection for Cultural Displays. In The Evolution of Culture, R. Dunbar, C. Knight, and C. Power, eds. Pp. 71-91. Edinburgh: Edınburgh Unıversity Press.

1999b Waste Is Good. Prospect (February):18-23.

2000a The Mating Mind: How Sexual Choice Shaped the Evolution of Human Nature. New York: Doubleday.

2000b Mental Traits as Fitness Indicators: Expanding Evolutionary Psychology's Adaptationism. In Evolutionary Perspectives on Human Reproductive Behavior, D. Lecroy and P. Moller, eds. Pp. 62-74. Annals of the New York Academy of Sciences 907.

2000c Sexual Selection for Indicators of Intelligence. In The Nature of Intelligence, G. R. Bock, J. A. Goode, and K. Webb, eds. Pp. 260-275. Novartis Foundation Symposium 233. New York: John Wiley.

2000d Evolution of Human Music through Sexual Selection. In The Origıns of Music, N. L. Wallin, B. Merker, and S. Brown, eds. Pp. 329-360. Cambridge: MIT Press.

2001 Aesthetic Fitness: How Sexual Selection Shaped Artistic Virtuosity as a Fitness Indicator and Aesthetic Preferences as Mate Choice Criteria. Bulletin of Psychology and the Arts 2:20-25. 
Møller, A. P., and R. V. Alatalo

1999 Good Genes Effects in Sexual Selection. Proceedings of the Royal Soctety of London $B$ 266:85-91.

Moller, A. P., and M. Petrie

2002 Condition Dependence, Multiple Sexual Signals, and Immunocompetence in Peacocks. Behavioral Ecology 13:248-253.

Mueller, U., and A. Mazur

2001 Evidence of Unconstrained Directional Selection for Male Tallness. Behavioral Ecology and Sociobiology 50:302-311.

Nachman, M. W., and S. L. Crowell

2000 Estımate of the Mutatıon Rate per Nucleotide in Humans Genetics 156:297-304.

Pawlowski, B.

1999 Permanent Breasts as a Side Effect of Subcutaneous Fat Tissue Increase in Human Evolutıon. Homo 50:149-162.

Pawlowski, B., and R. I. M. Dunbar

1999 Withholding Age as Putative Deception in Mate Search Tactics. Evolution and Human Behavior 20:53-69.

Pawlowski, B., and S. Koziel

2002 The Impact of Traits Offered in Personal Advertısements on Response Rates. Evolution and Human Behavior 23:139-149.

Penton-Voak, I. S., and D. I. Perrett

2000 Female Preferences for Male Faces Changes Cyclically: Further Evidence. Evolutın and Human Behavior 21:39-48.

2001 Male Facial Attractıveness. Perceıved Personality and Shifting Female Preferences for Male Traits across the Menstrual Cycle. Advances in the Study of Behavior 30:219-259.

Penton-Voak, I. S., D. I. Perrett, D. L. Castles, T. Kobayashi, D. M. Burt, L. K. Murray, and R. Minamisawa

1999 Menstrual Cycle Alters Face Preference. Nature 399:741-742

Perusse, D.

1993 Cultural and Reproductive Success in Industrial Societies: Testrng the Relationship at the Proximate and Ultimate Levels. Behavioral and Brain Sciences 16:267-283.

Petrie, M.

1994 Improved Growth and Survival of Offspring of Peacocks with More Elaborate Trans. $\mathrm{Na}$ ture 371:598-599.

Pillsworth, E. G., M. G. Haselton, and D. M. Buss

2004 Ovulatory Shifts in Female Sexual Desire. Journal of Sex Research 41:55-65.

Postuma, D., E. J. C. De Geus, W F. C. Baare, H E. H. Pol, R. S. Kahn, and D. I. Boomsma 2002 The Association between Brain Volume and Intelligence Is of Genetıc Origin. Nature Neuroscience 5:83-84.

Prokosch, M., R. Yeo, and G. F. Miller

2005 Intelligence Tests with Higher g-Loadings Show Higher Correlations with Body Symmetry: Evidence for a General Fitness Factor Medrated by Developmental Stability. Intelligence 33:203-213.

Reynolds, D. J., and R. Gifford

2001 The Sounds and Sights of Intellıgence: A Lens Model Channel Analysıs. Personality and Social Psychology Bulletin 27:187-200.

Rice, W. R. and S. D. Gaines

1994 "Heads I Win, Ta1ls You Lose": Testıng Directional Alternative Hypotheses in Ecological and Evolutionary Research. Trends in Ecology and Evolution 9:235-237.

Rikowskı, A., and K. Grammer

1999 Human Body Odour, Symmetry and Attractiveness. Proceedings of the Royal Society of London B 266:869-874.

Ridley, $\mathrm{M}$.

2001 The Cooperative Gene: How Mendel's Demon Explains the Evolution of Complex Beings. New York: Free Press. 
Robson, A. J.

2001 The Biological Basis of Economic Behavior. Journal of Economic Literature 39:11-33.

Robson, A. J., and H. S. Kaplan

2003 The Evolution of Human Life Expectancy and Intelligence in Hunter-Gatherer Economies. American Economic Review 93:150-169.

Rowe, L., and D. Houle

1996 The Lek Paradox and the Capture of Genetic Variance by Condition Dependent Traits. Proceedings of the Royal Society of London B 263:1415-1421.

Saad, G., and T. Gill

2000 Applications of Evolutionary Psychology in Marketing. Psychology and Marketing 17:10051034.

Salmon, C., and D. Symons

2001 Warrior Lovers: Erotic Fiction, Evolution, and Female Sexuality. London: Weidenfeld and Nicholson.

Scheib, J. E.

1994 Sperm Donor Selection and the Psychology of Female Mate Choice. Ethology and Sociobiology 15:113-129.

2001 Context-Specific Mate Choice Criteria: Women's Trade-offs in the Contexts of Long-Term and Extra-Pair Mateships. Personal Relationships 8:371-389.

Scheib, J. E., S. W. Gangestad, and R. Thornhill

1999 Facial Attractiveness, Symmetry, and Cues of Good Genes. Proceedings of the Royal Soctety of London B 266:1913-1917.

Schmitt, D. P., and D. M. Buss

1996 Strategic Self-Promotion and Competitor Derogation: Sex and Context Effects on the Percerved Effectiveness of Mate Attraction Tactics. Journal of Personality and Social Psychology 70:1 185-1204.

Schmitt, D. P., and T. K. Shackelford

2003 Nifty Ways to Leave Your Lover: The Tactics People Use to Entice and Disguise the Process of Human Mate Poaching. Personality and Social Psychology Bulletin 29:1018-1035.

Shackelford, T. K., and R. J. Larsen

1999 Facial Attractiveness and Physical Health. Evolution and Human Behavior 20:71-76.

Shaner, A., G. F. Miller, and J. Mintz

2004 Schizophrenia as One Extreme of a Sexually Selected Fitness Indicator. Schizophrenia Research 70:101-109.

Simonton, D. K.

1999 Creativity as Blınd Variation and Selection Retention: Is the Creatıve Process Darwinian? Psychological Inquiry 10:309- 328.

Singh, D.

1995 Female Health, Attractiveness, and Desirability for Relationships: Role of Breast Asymmetry and Waist-to-Hip Ratio. Ethology and Sociobiology 16:465-481.

Sluming, V. A., and J. T. Manning

2000 Second to Fourth Digit Ratio in Elite Musicians: Evidence for Musical Ability as an Honest Signal of Male Fitness. Evolution and Human Behavior 21:1-9.

Smith, E. A., and R. B. Bird

2000 Turtle Hunting and Tombstone Opening: Publıc Generosity as Costly Signaling. Evolutıon and Human Behavior 21:245-261.

Soler, C., M. Nunez, R. Gutierrez, J. Nunez, P. Medina, M. Sancho, J. Alvarez, and A. Nunez 2003 Facial Attractiveness in Men Provides Clues to Semen Quality. Evolution and Human Behavior 24:199-207.

Sosis, R., S. Feldstein, and K. Hill

1998 Bargaining Theory and Cooperative Fishing Participation on Ifaluk Atoll. Human Nature 9:163-203.

Sternberg, R., ed.

1999 Handbook of Creativity. Cambridge: Cambridge University Press. 
Strassman, B. I.

1997 The Biology of Menstruation in Homo sapiens: Total Lifetime Menses, Fecundity, and Nonsynchrony in a Natural-Fertility Population. Current Anthropology 38:123-129.

Sunyaev, S., V. Ramensky, I. Koch, W. Lathe, A. S. Kondrashov, and P. Bork 2001 Prediction of Deleterious Human Alleles. Human Molecular Genetics 10:591-597.

Tessman, I. 1995 Human Altruism as a Courtship Display. Oikos 74:157-158.

Thornhill, R., and S. W. Gangestad 1999 The Scent of Symmetry: A Human Pheromone That Signals Fitness? Evolution and Human Behavior 20:175-201.

Thornhill, R., S. W. Gangestad, and R. Comer 1995 Human Female Orgasm and Mate Fluctuating Asymmetry. Anmmal Behavior 50:1601-1615.

Thornhill, R., S. W. Gangestad, R. Miller, G. Scheyd, J. K. McCullough, and M. Franklın 2003 Major Histocompatibility Complex Genes, Symmetry, and Body Scent Attractiveness in Men and Women. Behavioral Ecology 14:668-678.

Thornhill, R., and K. Grammer

1998 The Body and Face of Woman: One Ornament That Signals Quality? Evolution and Human Behavior 20:105-120.

Thornhill, N. W., and R. Thornhill

1990 An Evolutionary Analysis of Psychological Pain following Rape, 2: The Effects of Stranger, Friend, and Family-Member Offenders. Ethology and Sociobiology 11:177-193.

Tooby, J., and L. Cosmides

1992 The Psychological Foundations of Culture. In The Adapted Mind: Evolutionary Psychology and the Generation of Culture, J. H. Barkow, L. Cosmides, and J. Tooby, eds. Pp. 19-136. New York: Oxford University Press.

Udry, J. R., and N. Morris

1968 Distribution of Coitus in the Menstrual Cycle. Nature 200:593-596.

Veblen, $\mathrm{T}$.

1899 The Theory of the Letsure Class. Reprinted in 1994 by Dover, New York.

Von Schark, C. P., R. O. Deaner, and M. Y. Merrill

1999 The Conditions for Tool Use in Primates: Implications for the Evolution of Matenal Culture. Journal of Human Evolution 36:719-741.

Waynforth, D.

2001 Mate Choice Trade-offs and Women's Preference for Physically Attractive Men. Human Nature 12:207-219.

Whissell, C.

1996 Mate Selection in Popular Women's Fiction. Human Nature 7:427-447.

Whiten, A., and R. W. Byrne, eds.

1997 Machiavellian Intelligence II Extenstons and Evaluations. New York: Cambridge University Press.

Zahavi, A., and A. Zahavi

1997 The Handicap Principle: A Missing Plece of Darwin's Puzzle New York: Oxford Unıversity Press.

Zebrowitz, L. A., J. A. Hall, N. A. Murphy, and G. Rhodes

2002 Looking Smart and Looking Good: Facial Cues to Intelligence and Therr Origins. Personality and Social Psychology Bulletin 28:238-249.

Zechner, U., M. Wilda, H. Kehrer-Sawatzki, W. Vogel, R. Fundele, and H. Hameister

2001 A High Density of X-Linked Genes for General Cognitive Ability: A Run-Away Process Shaping Human Evolution? Trends in Genetics 17:697-701. 